Cumhuriyet University

Journal of Economics and Administrative Sciences

E-ISSN: 2687-4032

2022, 23(1), pp.362-384.

Doi: 10.37880/cumuiibf.1014131

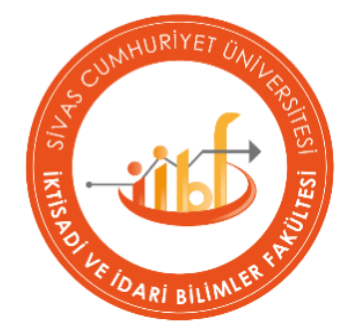

\title{
RUSSIAN ORTHODOX CHURCH AND COVID-19 PANDEMIC: NEW CHALLENGES AND NEW OPPORTUNITIES
}

\section{Viktoriia DEMYDOVA ${ }^{1}$}

\section{Abstract}

COVID-19 pandemic that reached Russia in March 2020, affected the Russian Orthodox Church (ROC) in a negative way. Following the recommendations about the closure of the churches in Russia in late March 2020, ROC confronted serious challenges. This article problematizes the position of ROC that faced a dilemma whether to close churches and put some of them onto the brink of poverty, or to perform religion's main function and support citizens morally and spiritually. This article seeks to answer the question about the impact of COVID-19 pandemic on the Russian Orthodox Church. It is argued that ROC has been affected by pandemic to a significant extent. First, ROC faced troubles in its relations with the government. Till the last minute, churchmen were resisting the decision of the authorities to close the churches. Second, COVID-19 pandemic posed a threat to the position of ROC in Russian society: flock had distanced from the Church due to the isolation measures adopted. Third, the financial contributions of the citizens have deteriorated which has led to the financial crisis within the Church. Fourth, split between different groups of clergy has deepened during the pandemic. Finally, pandemic caused not only new challenges but also new opportunities for ROC. Thus, there is a chance to launch online services to avoid a gap between the flock and the Church. Second, the Church has the chance to redefine its ideology and worldview to address new issues of the post-COVID world. The author concentrates on the period between March 2020 and October 2021 and embraces qualitative methodology.
Article History:

Date submitted:

24 October 2021

Date accepted:

28 December 2021

Jel Codes:

$H 70, N 90$

Keywords:

COVID-19, Moscow

Patriarchate,

Orthodox Church,

Pandemic, Russia.

Suggested Citation: Demydova, V. (2022). Russian Orthodox Church and Covid-19 Pandemic: New Challenges and New Opportunities. Cumhuriyet University Journal of Economics and Administrative Sciences, 23(1), 3625-384.

${ }^{1}$ Asst. Prof. Dr., Istanbul Gelişim University, Faculty of Economic, Administrative and Social Sciences, Department of Political Science and International Relations, demydovav@gmail.com, ORCID ID: 0000-00015447-1033. 


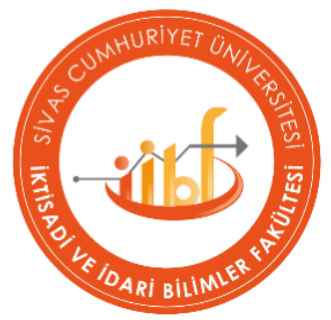

\section{RUS ORTODOKS KILISESI VE COVID-19 PANDEMISİ: YENI ZORLUKLAR VE YENI FIRSATLAR}

\section{Viktoriia DEMYDOVA ${ }^{1}$}

\section{$\ddot{O} z$}

Mart 2020'de Rusya'ya ulaşan COVID-19 pandemisi, Rus Ortodoks Kilisesi'ni (ROK) olumsuz yönde etkiledi. Rusya'daki kiliselerin Mart 2020'nin sonlarında kapatılmasına ilişkin tavsiyelerin ardından Rus Ortodoks Kilisesi, ciddi zorluklarla karşı karşıya kaldı. Bu makale, kiliseleri kapatıp bazllarını yoksulluğun eşiğine getirmek veya dinin temel işlevini yerine getirmek ve vatandaşları ahlaki ve ruhsal olarak desteklemek gibi bir ikilemle karşı karşıya kalan ROK'nin konumunu sorunsallaştırmaktadır. Bu makale, COVID-19 pandemisinin Rus Ortodoks Kilisesi üzerindeki etkisi hakkındaki soruyu yanıtlamayı amaçlamaktadır. ROK'nin pandemiden önemli ölçüde etkilendiği iddia edilmektedir. İlk olarak, ROK hükümetle ilişkilerinde sorunlarla karşılaştı. Kilise mensupları, yetkililerin kiliseleri kapatma kararına son dakikaya kadar direndiler. İkincisi, COVID-19 pandemisi, ROK'nin Rus toplumu içindeki konumuna bir tehdit oluşturdu: cemaat, alınan izolasyon önlemleri nedeniyle Kilise'den uzaklaştı. Üçüncüsü, vatandaşların maddi katkıları azaldı ve bu da Kilise içinde finansal krize yol açtı. Dördüncüsü, farklı din adamı grupları arasindaki bölünmeler salgın sirasında derinleşti. Son olarak, pandemi ROK için sadece yeni zorlukları değil, aynı zamanda yeni firsatları da beraberinde getirdi. Nitekim cemaat ve Kilise arasındaki boşluğu doldurmak için çevrimiçi hizmetler başlatma şansı doğurdu. Ayrıca Kilise, post-COVID dünyasının yeni sorunlarını ele almak için ideolojisini ve dünya görüşünü yeniden tanımlama şansina sahip oldu. Yazar, Mart 2020 ile Ekim 2021 arasindaki döneme odaklanmakta ve nitel araştırma metodolojisini benimsemektedir.
Makale Geçmişi:

Iletilen Tarih:

24 Ekim 2021

Kabul Tarihi:

28 Aralk 2021

Jel Kodlarl:

H70, $N 90$

Anahtar Kelimeler:

COVID-19, Moskova

Patrikhanesi,

Ortodoks Kilisesi,

Pandemi, Rusya.

Önerilen Alıntı: Demydova, V. (2022). Rus Ortodoks Kilisesi ve Covid-19 Pandemisi: Yeni Zorluklar ve Yeni Fırsatlar. Cumhuriyet Üniversitesi İktisadi ve İdari Bilimler Dergisi, 23(1), 362-384.

${ }^{1}$ Dr. Öğr. Üyesi, İstanbul Gelişim Üniversitesi, İktisadi, İdari ve Sosyal Bilimler Fakültesi, Siyaset Bilimi ve Uluslararası İlişkiler Bölümü, demydovav@ gmail.com, ORCID ID: 0000-0001-5447-1033. 


\section{INTRODUCTION}

COVID-19 pandemic that started to spread around the world in late 2019, posed a threat not only to the stability of the Russian government or Russian economy but also affected the Russian Orthodox Church (ROC) in a negative way. Following the recommendations about the closure of the churches in Russia in late March 2020, ROC confronted significant changes. First, leadership of the Russian Orthodox Church tried to resist the decision of the government about suspension of religious services. Inability to provide moral and spiritual support to the people would mean the inability to fulfill the main function of the Church. Donations which are the main source of the ROC's income did not arrive. Finally, representatives of the Russian Orthodox Church appeared to be divided in their attitudes towards the bans.

This article problematizes the position of ROC that faced the following dilemma. On the one hand, closed churches could not provide spiritual and moral support to the people who sought reinforcement in times of pandemic and economic deterioration. In contrast, the decision to continue services would mean ignoring statistics of the growing number of COVID-19 cases in the country. Furthermore, the Russian Orthodox Church could not get donations, which are an important source of income for the Church; while other sources such as the sale of candles and services were cut as well. This put many periphery units of the Church on the brink of poverty. This article seeks to answer the question about the impact of the COVID-19 pandemic on Russian Orthodox Church in the period between March 2020 and October 2021. It is argued that ROC has been affected by the pandemic in many ways. First, ROC had a disagreement with the Russian government. Till the last minute, churchmen were resisting the decision of authorities to close the churches. But as soon as Patriarch Kirill had urged for home prayers, it became clear that the 'symphony of powers' no longer existed. Rather, the Church appears to be under the control of the state. Second, the COVID-19 pandemic posed a threat to the position of ROC in Russian society: flock had distanced from the Church due to the isolation measures adopted. Third, the financial contributions of the citizens deteriorate that had led to the financial crisis within the Church. Fourth, the COVID-19 pandemic and corresponding measures of the authorities jeopardized existing cleavages between different groups of clergy in ROC. While the radical conservative party desires to continue religious services in Russian churches and opposes their closing, a liberal group of clergy urges people for home prayers. Finally, the pandemic caused not only new challenges but also new opportunities for ROC. Among them, there is a chance to launch online services in order to avoid a gap between the flock and the Church. Second, the Church has the chance to redefine its ideology and worldview to address new challenges of the post-COVID world.

This article is a case study of the changes in the Russian Orthodox Church during the COVID-19 pandemic. Data collection techniques include analysis of the official documents of the Russian government, presidential decrees, local administration, and releases of ROC and churchmen accompanied by the study of the media content related to ROC. The time period covered in this article is between March 2020 and October 2021.

The article is organized as follows. The author starts with an overview of the main measures that regulated religious activities in Russia in the mentioned period. Then, cleavages between Russian authorities and ROC are discussed, followed by the analysis of the changes in the Church's economic situation during pandemic, as well as split among the clergy. The author also analyzes online practices of ROC, and finally, elaborates on the future of ROC after the 
Viktoriia DEMYDOVA, 2022 Cilt: 23, Sayl: 1, ss.362-384.

pandemic. Concluding remarks summarize the main findings of the research and provide brief recommendations.

\section{RUSSIAN ORTHODOX CHURCH AND COVID-19}

This section of the article focuses on the decisions of the federal and local governments that directly or secondhand affected the Russian Orthodox Church during the COVID-19 pandemic. Also, the author shows main changes in ROC and activities of the Moscow Patriarchate in the early period. Discussion in this section reflects the lack of the centralized decision-making of the government and the Church, as well as expanding restrictive nature of the measures. Correspondingly, escalation of the contradictions between the Church and Russian authorities as to the functioning of the Orthodox religious institutions in Russia is detected in the mentioned period.

Chronology of the decisions. While the first cases of COVID-19 were seen in Russia in January 2020, the spread of the virus was registered in March. Enactments introduced by the government included cancellation of the events, closing schools, theatres, and museums, as well as shutting the border and declaring a non-working period which (after two extensions) lasted until 11 May 2020. Correspondingly, Russian regions started to announce lockdowns. Despite adopted measures, the number of cases kept growing in May, i.e. after the end of the six-week lockdown.

According to the 7 March statement of the Vatican's press office, Pope was going online. (Allen, 2020). In this early stage, ROC was sure that no government can force them to close the churches. This is illustrated by the Chairman of the Department for External Church Relations of the Moscow Patriarchate, Metropolitan of Volokalam Hilarion's statement dated by 18 March 2020:

The hierarchy of the Russian Orthodox Church is not considering any options for combating the coronavirus that involves the closure of churches, a forced reduction in the number of believers at worship, or a complete transfer of services from offline to online. Both, during Lent and Easter, real services will be held with the participation of real parishioners. (Russian Orthodox Church, 2020b).

Nevertheless, Metropolitan Hilarion (Alfeyev) admitted that ROC had understood the nature of the disease and would treat it correspondingly, therefore, several measures would be adopted. These would include the use of the sanitizers for the spoons, disposable gloves, refrainment from kissing the Chalice. (Russian Orthodox Church, 2020a).

On 25 March 2020, Russian President Vladimir Putin declared the first non-work week between 30 March and 3 April. (President of Russia, 2020). On the next day, Moscow city mayor Sergei Sobyanin recommended citizens to avoid mass gatherings, including Church services. (Sergey Sobyanin's website, 2020). Special Working Group established by the Moscow Patriarchate to coordinate Church's activities during the pandemic commented on Sobyanin's decision and announced desire to support flock that finds it necessary to attend churches. (Russian Orthodox Church, 2020d). On the same day, St. Petersburg governor announced ban on attending churches and other religious institutions for people except the churchmen. (St. Petersburg's City Administration, 2020). Responding to this ban, Patriarchate used articles 28 and 55 of the Constitution as well as the Russian Law On Freedom of Conscience and Religious 


\section{RUSSIAN ORTHODOX CHURCH AND COVID-19 PANDEMIC: NEW CHALLENGES AND NEW OPPORTUNITIES}

Associations stating that decision of the St. Petersburg's administration violates basic rights and freedoms. (Russian Orthodox Church, 2020d***). However, the Church's resistance to the measures of the authorities could not last long taking into consideration a growing number of cases. With the growth of the cases from 163 on 25 March to 290 per day on 29 March, the head of the Russian Orthodox Church, Patriarch Kirill (Gundyaev) himself called for avoiding attending the churches and asked people to think "why this is happening". ("Patriarkh Kirill utverdil", 2020). On 10 April, Patriarch Kirill finally undertook responsibility and issued a list of recommendations as to the Church rules during the Lent and Easter. In the text, it was indicated that "clergy of the monasteries and parishes, guided by the blessing of the Patriarch, is recommended to call parishioners for home prayers till the end of the restrictions imposed by the authorities". As it can be concluded from the document, the implementation of the recommendations was left to the discretion of the diocesan bishops similar to the federal government's resolution to pass all the decision-making responsibilities to the governors. (Agency for Strategic Communications, 2020, p.5).

God in the new Russian Constitution. Nevertheless, the Russian government continued to use religion in its conservative populist propaganda. While amending the 1993 Russian Constitution in 2020, the special commission came up with the decision to mention God in the new version of the main law. It would not only remind Russians about their identity and traditional values of the state, but will also satisfy the churchmen whose special for the state position once again was underlined. On 1 July 2020, constitutional amendments were adopted through the all-Russian referendum. Article 67 proclaims that Russian Federation is united not only by its history but also by the "belief in God". (Demydova, 2020, p.155).

The spiritual life of Russians in the early months of the pandemic. Ordinary Russians' spiritual life was affected by the ban on mass gatherings in many ways. Thus, Russians could not obtain spiritual support from religious institutions as they got used to. Also, cemeteries were closed so Russians could not attend the tombs of their relatives before and after Easter as Orthodox traditions demand. ("Koronavirus menyayet traditsii", 2020). Moreover, Easter 2020 was celebrated without visitors in the churches. ("Khristos Voskres!", 2020). Church services where only priests could stay were broadcasted instead. Having realized the necessity to redefine the tools of the Church, ROC launched the project of communication with the churchmen through the social network Odnoklassniki that will be discussed below. (Russian Orthodox Church, 2020d**). Russian Orthodox Church also was organizing charity events during the pandemic, fundraising campaigns for Russians and abroad, and supporting elderly and ill people. Special groups that would help in the hospitals, or visit elderly and disabled people were formed in the churches. (Russian Orthodox Church, 2020e).

Church and international affairs. To draw the attention of Russians away from the domestic issues, major media outlets started concentrating on the international dimension of Orthodoxy. Here, St. Sofia Church in Istanbul that had been transformed into the mosque became an agenda for the Orthodox clergy. ROC even expressed its concern over this decision of Ankara: Russian churchmen were reminded about the role of the church in Christianity and about the art of frescoes in the religious buildings that bear not only spiritual but also cultural and historical significance. ("Mitropolit Ilarion obespokoyen", 2020). The international dimension of the Church's affairs can be seen in the record of the cases in Kyiv and other parts of the Church. The office of the Moscow Patriarch did not hide the data as to the new cases in ROC abroad. 
Viktoriia DEMYDOVA, 2022 Cilt: 23, Sayl: 1, ss.362-384.

Memory construction. At the same time, a memory construction project started in the Church. "Church During the Pandemic" was the photo exhibition launched by the Moscow Patriarchy to preserve memorable moments of the pandemic. (Russian Orthodox Church, 2020h). Photos that were collected via email complemented citations from the priests' sermons about the faith in the pandemic. Having suspended religious services in Russian churches, ROC seemed to withdraw spiritual and moral support for the people. Correspondingly, the necessity to create a positive image of the Church that was working for its laity during the lockdowns motivated Moscow Patriarchate to launch a web page. It was a strategic move, since Russians were locked in their houses and the Internet remained the only channel of communication.

\section{CLEAVAGES WITH THE GOVERNMENT}

As it was discussed above, a contradiction between the leaders of ROC and Russian government is rooted in the positions of both institutions over the pandemic and measures to curb it. Thus, in March 2020, during the Sunday service in Moscow suburban Peredelkino, Patriarch of All Russia Kirill announced that the pandemic is the "mercy of God". ("Patriarkh Kirill prizval", 2020). As he explained, pandemic was a historical chance to realize the weakness of civilization and reassess human abilities. Patriarch expected an increase in the number of Church's visitors and consequently a growth of the Church's income.

It is noteworthy that the Church's leadership and particularly Patriarch Kirill preferred to stay away from the direct negotiation of the situation over the closed churches with the authorities. On the one hand, loyal to the government Patriarch Kirill obeyed the decision of the government and the main sanitary doctor and recommended citizens to stay home. On the other hand, he performed services in the cathedral. (Luchenko, 2020). Thus, after the publication of the 10 April recommendations of the Working Group, Patriarch Kirill disappeared from the public sphere. This provoked discussion in the media space about the options for holding the 2020 Easter service. It should be noted that back on 26 March 2020, the Legal Department of the Moscow Patriarchate rebuked the decision of the Government of St. Petersburg, according to which, visits to churches were prohibited. From the Patriarchate's point of view, there was no legal basis for the secular authorities to prohibit church visits unless an emergency or quarantine regime has been introduced. As a result, within the St. Petersburg diocese, it was forbidden to attend Easter service in St. Petersburg, but in the Gatchina, Vyborg, and Tikhvin dioceses (in the St. Petersburg region), it was possible. Therefore, many Russian citizens had moved to neighboring regions to attend cathedrals personally. (Agency for Strategic Communications, 2020, p.7). As a Russian expert on ROC Kseniya Luchenko (2020) puts it, "there has been... a decentralization, possibly situational and temporary [in the Church] ${ }^{1}$. The bishops suddenly remembered that according to the canons, each of them is the head of the local church, and the patriarch is only "the first among equals". (Luchenko, 2020). The interview of Metropolitan Hilarion supports this idea. Answering the question about Holy Week, Easter, and religious processions in 2020, Hilarion said that it would depend on the situation in the region, (Russian Orthodox Church, 2020c) therefore leaving the right to come up with the final decision to the local clergy rather than proclaiming a unified strategy of the Church obligatory for all units within its hierarchy.

${ }^{1}$ Emphasized by author 


\section{RUSSIAN ORTHODOX CHURCH AND COVID-19 PANDEMIC: NEW CHALLENGES AND NEW OPPORTUNITIES}

Furthermore, one can trace growing tensions between the Russian Orthodox Church and authorities. An example of the growing criticisms expressed by the COVID-dissidents in the Church is an idea about the resemblance between the current position of the authorities to the policies of the Soviet state. He was Metropolitan Longin of Saratov who compared the ban on visiting churches with the persecution of the Church in the Soviet period. He threatened with a curse all those who would impose or obey such restrictions, warning that those who follow the directions of the health authorities and who violate the precepts of the faith will be "held accountable." ("Saratovskiy mitropolit vystupil”, 2020). Nikita Badmayev, an archpriest of the St. Seraphim of Sarov Church in St. Petersburg, criticized the decision of the authorities and declared that

... our services - joint meetings for prayer - come in a common "package" with restaurants, cinemas, shopping malls and other public places. For the secular authorities and doctors, it does not matter why people get together - to hang out or to pray. And therefore, church resistance and defending their rights to meetings is a challenge not only to the authorities, but also to the entire humanistic society. (Badmayev, 2020).

Provoking a conflict between people and government he basically the jeopardized situation in the society instead of calling people for patience and understanding, two basic Christian virtues.

The dissatisfaction of the Church with the bans on mass gatherings can be seen in its resolution to postpone the opening of the cathedral dedicated to the Russian Armed Forces. Russian Orthodox Church and Russian Army are two of the most trusted institutions in Russian society. (WCIOM, 2021). This cathedral had been conceived as a symbol of the close relationship between ROC and the state and had been erected in the Patriot park near Moscow. Initially, it was planned to open on 9 May, on the day of the 75th anniversary of the victory over Nazi Germany. The cathedral was to be decorated with a mosaic depicting Putin, his defense minister, and other statesmen, including Stalin, who led the Soviet Union during the war. However, amid the growing tensions between the state and the Church over the pandemic, ROC's representative announced that Putin's mosaic would be removed at the Kremlin's request. ("Mozaiku s Putinym ubrali”, 2020).

At the moment, one can witness how, as Andrew Higgins (2020) puts it, ROC loses its trust in the authorities. For a long time, the Russian Orthodox Church and Russian authorities had been collaborating in domestic and foreign affairs. The trade-offs of this partnership had been mutual. In the domestic sphere, Kremlin used the support of the Church to spread conservative values in Russian society through education, culture and legislation. In foreign affairs, ROC had been a tool of Kremlin's soft power through the Russian World that had rested on two columns: Russian language and Orthodox Christianity. It even helped Moscow to justify the annexation of Crimea from the spiritual point of view: a place, where Prince Vladimir was baptized is located near Crimean town Sevastopol. In 2021, celebrating the anniversary of Crimea's annexation, Russian President Vladimir Putin underlined the importance of the region as a cradle of Christianity in the Ancient Rus'. In its turn, in both domestic and foreign affairs, ROC had obtained numerous lands and monasteries as well as believers who used to support the Church with their donations exempted from the taxes. However, with the Ukrainian crisis of $2013-2014$ and subsequent annexation of Crimea, ROC faced the loss of supporters in Ukraine, since it had been associated with the aggressive politics of the Kremlin. Later, when the new Ukrainian Church was founded, the collapse of the Russian World became obvious. ROC not only started to 
Viktoriia DEMYDOVA, 2022 Cilt: 23, Sayl: 1, ss.362-384.

lose believers from Ukraine but it also lost significant properties and leverage of influence on the laity. (Demydova, 2019).

Moreover, Russia's populist leadership, despite being conservative in its public discourses, does not support ROC on many issues. The issue of the de-legitimization of abortions, as well as the issue of properties, are two the most vivid examples. Particularly, many Russian cathedrals that are being used as museums at the moment, for example, the Isaakievsky Cathedral of St. Petersburg, cannot be transferred to the Church that also provokes dissatisfaction among the clergy. (Demydova, 2019, p.257). And when it comes to the discussion of the Constitutional provision that mentions God, it should not be misread that neither Orthodoxy nor ROC is mentioned. "Belief in God" as it is formulated in the Constitution can be seen as an attempt to appeal to all confessions existing in the Russian Federation or an attempt to avoid exclusion of Muslims, Buddhists or Jewish citizens. Here, the conservative nature of the Russian regime is declared but the specific confession is not given a priority. Therefore, taking together all these policies of the Kremlin seem to undermine ROC's status in society and the international relations that are being very painful for the Moscow Patriarchate. Correspondingly, one should expect withdrawal of the Church's support for the state.

\section{FINANCIAL ISSUES IN THE CHURCH}

To understand the impact of the pandemic on the financial stand of the Church one should examine the sources of the Church's income. Russian Orthodox Church is legally registered as a religious organization that is a subtype of a non-profit organization. Individual parishes also have the status of legal entities, and, as a rule, they are self-sufficient, keep accounting and submit tax reports. Such a legal entity may not pay VAT and income tax, but only if certain conditions are met. First, the income must be spent on statutory activities of the founding religious organization (that is, missionary work, charity, and so on). Secondly, it concerns the enterprises that produce or sell religious items. The list of the items is approved by the government: icons, candles, incense, special clothing, spiritual literature, video, and audio materials are allowed. The Church is also exempt from the tax on property and land under the buildings used for religious and charitable purposes. ("Tserkov' i nalogi", 2019).

According to Russian law, the government provides support to socially-oriented NGOs and volunteer organizations. The forms of such support may differ: property, information, personnel training, or financial aid are the options. Furthermore, all religious organizations in Russia, regardless of denomination, have the same taxation conditions. They must pay excise taxes, transport tax, personal income tax, and insurance premiums from the employees' salaries. Therefore, the income of the Church comes from the enterprises owned by it, as well as from the "income not prohibited by law, including income from securities and deposits placed in deposit accounts." But the most important source is donations, sponsorship, financing of individual projects, and the government's aid. ("Tserkov' i nalogi", 2019).

COVID-19 pandemic led to a significant deterioration in the economy of the country, which also affected the Russian Orthodox Church. Particularly, provincial churches of ROC suffered severely. ("Svyashchennik rasskazal, kogda", 2020). While some of them chose to fire the personnel, the others had to organize a fundraising campaign in order to cover the main expenses. Since people do not attend cathedrals and churches, there are practically no donations. ("Cherepovetskiye khramy s trudom”, 2020). Besides, the Russian Orthodox Church also lost 
significant properties during the Ukrainian crisis and the December 2018 autocephaly of the Ukrainian Church. Therefore, the economic situation in the Russian Orthodox Church is deplorable and drew the attention of the authorities and Patriarchate. Thus, the chairman of the State Duma's committee on civil society Sergey Gavrilov underlined that socially-oriented NGOs suffered a crisis in the period of the pandemic, therefore the Russian government is willing to support them. (Russian Orthodox Church, 2020g). Having realized the level of the economic crisis in the Church, Patriarch Kirill asked wealthy parishioners to help:

But just as faith without love does not bring any benefit to a person, so Christian compassion should have visible fruits. That is why I turned to people who are wealthy and benevolent to the Church with a humble request to provide material support to our clergy. And thanks be to the Lord, my prayers were heard. Of course, maybe this will not radically change the situation, but each of us must do what is in his power today. (Russian Orthodox Church, 2020f).

Moreover, despite the discussed above cooling down in the relations with the authorities, Patriarch Kirill appealed to the federal authorities with a request "to consider the issue of granting religious organizations a deferral of payment of utility bills for a period until the abolition of restrictive measures and the resumption of full-fledged work of churches and monasteries". ("Patriarkh poprosil vlasti", 2020). Correspondingly, State Duma approved an amendment to exempt religious organizations from paying taxes and insurance premiums for the second quarter of 2020 due to the pandemic. ("Deputaty osvobodili religioznyye", 2020).

To sum up, even though many sectors of the Russian economy, as well as groups in Russian society, demanded financial support from the government, Russian authorities, among others, chose to support religious institutions, including ROC, even though in a very modest way.

\section{CONFLICT WITHIN THE CHURCH}

A split between the hardline fundamentalist Orthodox clergy and moderate liberals is not new, however, it aggravated during the pandemic. Their views differ when it comes to numerous issues, such as abortions, relations with the authorities and policies during the pandemic. The brightest liberal preachers in the Church are the heads of the Moscow communities Georgy Kochetkov, Alexander Borisov, Alexei Uminsky, professor of the St. Petersburg Theological Academy Georgy Mitrofanov, and Abbot Pyotr Mescherinov. The most influential figure in the authoritarian camp is Metropolitan Tikhon Shevkunov, founder of Pravoslavie.ru and Sretensk Seminary. Tikhon lobbies for state-conservative propaganda and is famous for the exhibition "Russia: My History", where devotion to authorities is presented as a popular ideal. Sretensk Seminary gathered teachers of the protective warehouse, opponents of changes in the Church. The opposite vector in education is represented by the St. Philaret Institute of Georgy Kochetkov. St. Philaret Institute seeks to renew the church life and is engaged in the translation of worship into modern language. This is almost the only center in Russia where humanistic theology, inspired by Russian philosophy, is developing. (Artem Naryshkin, 2020).

During the pandemic, the split between two groups of the clergy aggravated, since Coronavirus posed a threat to the activities of the churches. For example, Patriarch Kirill criticized those churchmen who wanted people to pray at the churches. ("Patriarkh Kirill raskritikoval", 2020). Patriarch initially hesitated to follow the instructions of the health authorities that people should avoid mass gatherings such as church services. Instead, he got into 
Viktoriia DEMYDOVA, 2022 Cilt: 23, Sayl: 1, ss.362-384.

a black Mercedes, taking the sacred icon with him, and drove around the Russian capital, saying a prayer on the way. (Higgins, 2020). But as concerns over the increase in the number of cases grew in Kremlin, Patriarch, in early April 2020, heeded the warnings of the health authorities and strongly urged believers not to attend church services on the Holy Week before Easter, which was celebrated on April 19. However, he allowed the dioceses to decide for themselves whether to conduct services or not. Many of those preferred to hold the services, especially the procession and liturgy on Easter night, because these are the most important events in the Orthodox calendar. Russian news agency RBC estimates prove that during Easter, churches were opened in 43 of Russia's 85 regions. (Higgins, 2020).

Along with the rational and humanist approach in ROC, one can witness the formation of the COVID dissidents' group of the clergy. Thus, a bishop from the northern Russian region Komi opposed restrictions on visiting churches, calling it an infringement on basic human rights and threatening to sue the responsible officials. He said ringing bells was the best way to fight the pandemic and stated that the word "coronavirus," derived from the Latin word "crown," or "associated with the coronation and reign of the Antichrist." Sergei Romanov, a priest from the industrial city of Yekaterinburg, also criticized authorities for banning mass gatherings, including church services. He claimed, "it was a part of a Satanic conspiracy assisted by the Jews". (Higgins, 2020).

During the first stage of the pandemic, a liberal group of clergy was declared "liberals" and "little faiths" by the hardliners. The latter called "if necessary, to accept the martyr's crown," but not to change anything in the traditional way of liturgical life. The position of the "martyrs" was shared by the largest monasteries and by Archpriest Andrei Tkachev who staged a performance on the ambo of his church, ridiculing the respiratory and other protection from the virus. Nevertheless, the chairman of the Department for External Church Relations, Metropolitan Hilarion (Alfeyev), called the dissident position "criminal", reminding its advocates about the responsibility for the future sufferings of people and great temptations for the Church, whose "temples" can become a place of mass infection. As to the liberals in the Church, Priest Georgy Kochetkov explicitly called to refuse the sacrament in the church; if necessary, to invite the priest to the house, observing sanitary precautions. (Soldatov, 2020).

As discussed above the clash of the two camps in the Russian Orthodox Church revealed a very dangerous tendency. Thus, for hardliners, the Church remains the superior value that overshadows the person. Any changes in the traditional way of life are opposed and rejected as a danger for the Church. Representatives of this group imply that real martyrs would die during the pandemic. In contrast, it is a humanistic liberal camp of the clergy that appeared to be concerned with the health of the people. It seems likely that the pandemic will challenge the ideologies of both camps and will show the need to redefine key values for both. Otherwise, the Church that does not care about the health and the lives of the people will not be popular. Apart from the cleavage among the churchmen, the weakness of the Moscow and All-Russian Patriarch Kirill as well as the lack of his trust in the government have become clear (Higgins, 2020) even for the ordinary citizens. Apparently, there are two main issues of that weakness. On the one hand, following the example of the federal authorities that allowed regional governments to act under the epidemiologic situation in the region, Russian Patriarch Kirill transferred the decision-making power to the regional churches. While Patriarch himself urged people to stay home, he could not be blamed for the decisions to stop services in the cathedrals. On the other hand, Patriarch Kirill 
lacked strong power to keep the two camps of the Orthodox clergy together without letting people notice the growing cleavage within the Church.

\section{ONLINE CHURCH}

One of the most popular measures to curb the growing number of the infected was a distant education and introduction of the home offices. Religious institutions in the world also followed the new practices. Thus, one of the first Churches to go online was the Holy See: the Vatican decided to start Livestream on March 7, 2020, given the enormous number of cases in Italy. Before ROC went Livestream, Moscow Patriarch Kirill also preferred long-distance activities: instead of the Internet, he used the helicopter to travel across the city.

In line with the initial statements of Hilarion against online services, on 19 March, 2020, the Committee for the Protection of Personal Data, together with the Institute of the Public Commissioner for Family Protection held a discussion about the role of digital platforms in society. The position of the Church on this issue was voiced by Archpriest Vadim Burenin, Deputy Chairman of the St. Petersburg Diocese's Department for the Relations between Church and Society. The priest noted that it is impossible not to recognize positive aspects of the transition to the digital format of various documents and databases. However, according to Burenin, in the Church's environment, there is a concern about the compulsion to switch to new electronic technologies. Believers are worried that a certain "electronic government" is being built in the system where a person is a number, a certain code. Without this code, it will be impossible to interact with the governmental agencies, including getting medical care, getting a job. Burenin expressed his worry that once a citizen manifests disloyalty to the current system, he may be simply erased from the system. Father Vadim summed up his speech with the words of Patriarch Kirill of 31 July 2019:

The Church is concerned with a man, his life and, perhaps, one of the most important dimensions of human life - human freedom. We should not buy any toys, including digital ones, so that at some point we do not become the slaves of this technological civilization, the control center of which will not be in our sovereign country. (Letopis' Yeparkhial'noy Zhizni, 2020).

Furthermore, in his interview in late March 2020, Metropolitan of Valakalam Hilarion rejected the possibility of the online community. Instead, he promised to organize a special procedure for attending elderly people. As analysis indicates, the Russian Orthodox Church is ready to use digital technologies to a certain extent: for educational purposes or the spread of knowledge and literature. However, Russian Orthodox churchmen reject the idea of the religious services to be provided online. This can be explained by the mere pragmatic considerations, i.e. the inability of the Church to obtain donations online that are crucially important for the financial wellbeing of the institution. Also, not all Christian rituals are possible online: baptism that foresees bathing or rituals that involve candles are difficult to conduct via the Internet.

Nevertheless, ROC started to use online services in order to provide psychological support for the people. One of the first experiments was held through the famous Russian social network Odnoklassniki. Six Orthodox priests from the different regions of Russia would maintain a hotline. They are Priest Svyatoslav Shevchenko (Blagoveshchensk), Priest Konstantin Maltsev (st. Leningrad, Krasnodar Territory), Priest Vladimir Panarin (Chelyabinsk), Priest Alvian Tkhelidze (Znamensk), Priest Vyacheslav Nefedov (Yaroslavl) and Archpriest Sergei Voronkin (Ust-Tarka village, Novosibirsk region). 
Viktoriia DEMYDOVA, 2022 Cilt: 23, Sayl: 1, ss.362-384.

Apart from the electronic libraries and online consultations, many Orthodox churchmen use web blogs to share their ideas with the laity. When face-to-face communication was not possible, blogging became an option for the priests who wanted to provide relief for the citizens. Thus, Pavel Velikanov, Nikita Badmayev, Alexander Shchipkov whose publications on the sense of pandemic are discussed below drew the attention of the people to the meaning of the pandemic.

\section{PATRIARCH KIRILL AND THE FUTURE OF THE CHURCH LEADERSHIP}

Patriarch Kirill himself appeared to be in a very troubling position. He attempted at balancing between all issues arising amidst the pandemic: to follow the instruction of authorities as to the home-prayers; to please the liberal group of the clergy that prioritized people's health; and to find financial sources for the Church. However, he seemed to provoke dissatisfaction of many actors: Kremlin did not expect demands of financial support even when it was a request to postpone the deadline for the bills; radical Orthodox clergy opposed the closure of the churches; and ordinary citizens were not satisfied with the Church that could not secure moral support for its laity but was eager to get sponsorship from the state. At the same time, the luxury life style of the top clergy, their cars, villas, and watches have been disturbing the liberal part of the Church as well as the laity. ("Pochemu lyudey volnuyet", 2019). Since ordinary people want the religious leader to guide them and serve as a role model, the inappropriate wealth of the top churchmen that does not correspond to their official income provokes criticisms. As a result, Patriarch Kirill is losing his status as a religious leader, as an administrator (Eggert, 2020), and as a source of legitimization for the Kremlin. Instead, Metropolitan of Pskov Tikhon (Shevkunov) who decided to close cathedrals upon the request of authorities, cut the donations and provided support for the priests in need (Tomilin, 2020), is going to strengthen his positions in the Church hierarchy.

Already in February 2021, he announced the collection of testimonies for the glorification of Archimandrite John (Krestyankin) as a saint. ("Metropolitan of Pskov and Porkhov", 2021). Such a move signaled Shevkunov's adherence to starchestvo or spiritual guidance as a way of religious practice. A starets is an elder of an Eastern Orthodox monastery who functions as venerated adviser and teacher. Elders or spiritual fathers are charismatic spiritual leaders whose wisdom stems from God as obtained from the ascetic experience. Shevkunov's appointment to Pskov in 2018 was treated as a preliminary step for the Patriarch's position insofar as he is considered as one of the most influential figures in the Russian Orthodox Church and is often called "Putin's confessor". Metropolitan is close with the Rotenberg brothers and baptized the daughter of the head of Rosneft Igor Sechin. ("Prosveshchennyy russkiy natsionalist", 2021).

\section{NEW PHILOSOPHY - POST-PANDEMIC REFORMATION OF ROC}

Russian Orthodox Church remains the second most trustable institution in the Russian society preceded by the Russian Army only. (WCIOM, 2021). This is a very important status that guarantees cooperation with the authorities as well as financial wellbeing. Taking into consideration this place of the Church, many representatives of the clergy have published essays or interviews related to the meaning of the COVID-19 pandemic for the Church and the people. While some of them called for a reassessment of the pandemic, others suggested reforms as a way to overcome the crisis that emerged during the pandemic. 


\section{RUSSIAN ORTHODOX CHURCH AND COVID-19 PANDEMIC: NEW CHALLENGES AND NEW OPPORTUNITIES}

Sense of pandemic was summarized by the Patriarch Kirill, as it follows: a current pandemic is designed to make people think about the fact that man does not live by bread alone, to think about the meaning of his life and his weakness, "because the tragic overestimation of human capabilities, supported by undoubted achievements in science and technology, have deprived many of a critical view on ourselves". ("Patriarkh Kirill ob"yasnil", 2020). The very conservative stand of the Moscow and All-Russia Patriarch is obvious here.

Archpriest Pavel Velikanov, a vice-rector at Moscow Orthodox Theological Academy, in his blog elaborated on the early regulations that prohibited mass gatherings and affected Church rituals. His main message is that God has been testing the faith of the Christians, checking whether the faith will get weaker once the buildings are closed and physical elements of the ritual, unnecessary decorations are not at the disposal of the believers. (Velikanov, 2020a). Velikanov seems to be calling for the simplification and purification of the Church, in a way that the faith, not the rituals, icons, or the painted eggs, in the Church should be a priority. Analyzing opposition to the decision not to open churches even for Easter, Velikanov says that God "Slightly reduced the degree of festive pathos. Slightly more infringed upon our willfulness by fasting." (Velikanov, 2020b).

In contrast, archpriest Nikita Badmayev, the priest at the temple of St. Seraphim of Sarov, argues that

We are being driven out of the temples. Not for faith or anti-revolutionary propaganda, not for violating public order or insulting the feelings of unbelievers. They are expelled under the pretext of being humane and understandable to everyone, both believers and unbelievers, because of their love for people, especially the elderly. Secular and ecclesiastical authorities are driving us out. (Badmayev, 2020).

In his blog, Alexander Shchipkov (2021), First Deputy Chairman of the Synod Department for Church Relations with Society and Media explained how new, post-pandemic ROC should act. Analysis of the suggestions indicates that the clergy is aware of the existing crisis and the decentralization of the Church will follow pandemics. Also, suggested reforms of the Church imply democratic equality of the units. Provisions presented by Shchipkov presume to establish a "confederation of free and independent parishes" with the horizontal structure; cancellation of the institution of the patriarchate and return to the synod system of government. What is more important, Shchipkov underlines the parliamentarism, or election of the episcopate and clergy, instead of succession principle. Moreover, the establishment of the trade union to oppose the politics of the episcopate as it is demanded by Shchipkov would weaken the latter making the Church open for the negotiation and opposition. Moreover, the creation of a laity movement, weakening of the monasteries, reforms of the iconography, architecture, and dress code, as well as the introduction of the Russian language that is supported by $75 \%$ of Russians ("Pochemu lyudey volnuyet", 2019), would bring the Church closer to the people. The necessity of this step is dictated by the results of the poll conducted at the end of March 2020, when only $36 \%$ of respondents said that the Church had a positive impact on Russian society, while $14 \%$ noted its negative impact, and $24 \%$ of the respondents indicated that the ROC did not affect the society. Taking into consideration a high level of trust, given results may indicate dissatisfaction of the citizens with the Church's activities. Moreover, answering the question "What statement or proposal of the representatives of ROC have you remembered recently?" $2 \%$ of the participants mentioned provision on the God in the Constitution. At the same time, $82 \%$ found it difficult to answer ("Polovina rossiyan otmetila", 2020) which shows a very low level of interest in religious 
Viktoriia DEMYDOVA, 2022 Cilt: 23, Sayl: 1, ss.362-384.

affairs. Provided results also indicate that the Church does not deliver its message to the vast majority of Russians or citizens who could not understand this message, for instance, because of the language used during the ceremonies. It is already clear, that Russians treat Orthodoxy as a part of the culture and do not know the basic religious texts or principles. Finally, a list of reforms complemented by Shchipkov would also include the transfer of control over financial flows to the white clergy or the laity. The latter is particularly crucial given the growing dissatisfaction of Russian with the wealth of the Church.

The prohibition for the Russian state to provide material, political and expert support to the Russian Church (opposing the Church and the state in order to weaken both historical institutions) is also important for the future of the Church. (Shchipkov, 2021). Today, 43\% of Russians believe that ROC influences the policies of the Russian authorities. Along with this, only $26 \%$ of the people believe that the Church has little influence on politics, while, $27 \%$ do not recognize the influence of the church on state policy. ("Polovina rossiyan otmetila", 2020).

As analysis of the clergy's estimations of the COVID pandemic and the following changes in the Church indicates, existing cleavages within the Church are jeopardized by the pandemic. While both camps of the clergy, conservative and liberal, urge to reassess the meaning of the coronavirus, their stands on the organization and policies in the Church differ. Particularly, the liberal part of the clergy uses pandemics in order to promote reforms that will make the Church more liberal, transparent, and close to the laity. Russian Orthodox Church can no longer be perceived as a rigid conservative institution known for its collaboration with the Kremlin in domestic and foreign affairs. In contrast, the voices of the liberal priests demanding changes are growing. If their position on the numerous issues will be supported by the ordinary people, as it could be seen in the case of the translation of the services into Russian, the authoritarian orthodox part of the Church will be less likely to resist. This group of the clergy will shrink. Since the domestic and foreign policies of the Russian leadership have already weakened the Church, the lack of trust in the government undermines ROC's self-assuredness. 


\section{CONCLUSION. COVID-19: CHALLENGES AND OPPORTUNITIES FOR THE RUSSIAN ORTHODOXY}

This article discussed the impact of the COVID-19 pandemic and the corresponding policies of the Russian authorities on the Russian Orthodox Church in the period between March 2020 and September 2021. The author showed that following the closure of the churches in Russia in late March 2020, ROC faced serious challenges, such as the financial crisis caused by the withdrawal of donations, cleavages with the authorities, split within the Church, and inability to provide support for ordinary Russians. It was also shown that for ROC, the COVID-19 pandemic has become an opportunity to reform itself and to produce a new, post-COVID worldview and philosophy.

A case study of the pandemic's impact on the Church allows us to come up with the following conclusions. COVID-19 and, what is more important, corresponding decisions of the Russian authorities provoked a serious crisis in ROC. A pandemic could not pass unnoticed for the Church: existing issues, such as a split among clergy or dissatisfaction with the corrupted nature of the Church aggravated. The long-lasting division of the clergy into liberal and conservative has grown during the pandemic due to the opposite views as to the bans on mass gatherings. Conservative groups underlined their adherence to the institution of the Church, while liberals demonstrated their humanism and expressed concerns about the health of the people. This split went further and undermined the enduring support of the Church to the state since the conservative group of clergy demanded to neglect official measures of the health authorities.

Nevertheless, ROC proved to be a tool of the government when the cathedrals were closed and the services for the people were banned. In this way, ROC failed to perform its most important function - to support the people spiritually and morally, although some priests were working online via hotlines or were distributing aid. While Church proved to be another ministry of the state, dissatisfaction with the way the government's foreign and domestic policies affect the Church, has grown. The economic crisis also affected ROC but its degree was different for different regions. While churches and cathedrals in the big cities, such as Moscow or St. Petersburg, did not feel the lack of donations significantly, provincial units that do not run businesses, for instance, candle factories or production of the souvenirs, were put to the edge of poverty. The latter had to raise funds to maintain the buildings, pay bills and salaries for the staff.

Furthermore, when it comes to the new, post-COVID Church, one can trace two important tendencies. Both groups, liberal and authoritarian, tried to understand the meaning of the pandemic. While the liberal group of priests used the opportunity to call for reforms that would make Church more democratic and transparent, much as disrupting its power vertical, the authoritarian part of ROC is calling for martyrdom or suffering in the name of the institution of the Church. As it can be seen in the example of the Metropolitan Tikhon (Shevkunov), the authoritarian component of the Church is likely to get stronger since incumbent Russian Patriarch Kirill has failed to manage the numerous crises.

Another relevant issue is the use of the Internet, which also appeared to be dividing the representatives of the Russian Orthodoxy into two groups. While a conservative group of the clergy rejects any online technologies except the electronic libraries, the liberal group actively uses them to support laity and promote reforms. Blogs, hotlines, social media are the channels of the clergy. Correspondingly, those young Russian Orthodox Internet users have the potential to become a social base for the transformations in the Church. 
Viktoriia DEMYDOVA, 2022 Cilt: 23, Sayl: 1, ss.362-384.

To conclude, pandemics, among others, demonstrated the need for reforms in the Church. Unification, modernization, humanistic approach, use of technologies are the keys for the stable place of the Church in Russian society, where it already occupies the second most important position. 


\section{REFERENCES}

Agency for Strategic Communications. (2020). Russkaya Pravoslavnaya Tserkov' V Usloviyakh Pandemii Sars-Cov-2. [Russian Orthodox Church in Conditions Pandemic Sars-Cov-2].

Agency of the City News "Moscow" (2020, March 2). Opros: 75\% Pravoslavnykh Rossiyan Podderzhali by Perevod Bogosluzheniy Na Russkiy Yazyk [Poll: 75\% of Orthodox Russians Would Support the Translation of Services into Russian]. https://www.mskagency.ru/materials/2977895

Allen, E. A. (2020, May 7). Pope Will Livestream Events to Avoid Vatican Crowds as Coronoavirus Fears Mount. CRUX. https://cruxnow.com/vatican/2020/03/pope-willlivestream-events-to-avoid-vatican-crowds-as-coronoavirus-fears-mount/

Artem Naryshkin: Fundamentalisty Protiv Liberalov: Protivostoyaniye Vnutri RPTS [Artem Naryshkin: Fundamentalists Versus Liberals: Confrontation Within the Russian Orthodox Church]. (2020, February 28). Snob.ru. https://snob.ru/entry/189444/

Badmayev, N. (2020, April 14). Slovo Svyashchennika Khrama Prp. Serafima Sarovskogo Na Serafimovskom Kladbishche, Protoiyereya Nikity Badmayeva [The Word of the Priest of the Temple of St. Seraphim of Sarov at the Serafimovskoye Cemetery, Archpriest Nikita Badmaev]. Temple of the Archangel Michael in Letov. https://www.letovochurch.ru/novosti/propovedi/slovo-svyashchennika-khrama-prpserafima-sarovskogo-na-serafimovskom-kladbishche-protoiereya-nikity-/

Cherepovetskiye Khramy S Trudom Nakhodyat Den'gi V Period Pandemii. [Cherepovets Churches Find Money with Difficulty During a Pandemic]. (2020, May 17). 35Media. https://35media.ru/news/2020/05/17/cherepoveckie-hramy-s-trudom-nahodyat-dengi-vperiod-pandemii

Demydova, V. (2019). Independence of the Ukrainian Church: How Russia is Losing its Soft Power Tool in Ukraine. Akademik Hassasiyetler, 6(11), 251-274.

Demydova, V. (2020). Russian Constitutional Amendments 2020: Social State or Putin Forever? Stratejik ve Sosyal Araştırmalar Dergisi, 4(2), 147-164. https://doi.org/10.30692/sisad.743373

Deputaty Osvobodili Religioznyye Organizatsii Ot Nalogov Na Vremya Pandemii [Mps Exempted Religious Organizations from Taxes During the Pandemic]. (2020, May 22). Interfax. https://www.interfax.ru/russia/709832

Eggert, K. (2020, April 22). Kommentariy: Epokha Patriarkha Kirilla Podkhodit K Kontsu [Commentary: The Era of Patriarch Kirill is Coming to an End]. DW. shorturl.at/gvwGV

Higgins, A. (2020, May 6). Utrata Doveriya: Pandemiya Razrushayet Svyazi Mezhdu Tserkov'yu I Rossiyskim Gosudarstvom (The New York Times, SSHA) [Loss of Trust: Pandemic Shatters Ties Between Church and Russian State (The New York Times, USA)]. Inosmi.ru. https://inosmi.ru/social/20200506/247376645.html

Khristos Voskres! Vo Vsekh Khramakh Rossii Proshli Prazdnichnyye Bogosluzheniya [Christ is Risen! Festive Services Were Held in All Churches of Russia]. (2020, April 19). Vesti.ru. https://www.vesti.ru/article/2400747 
Viktoriia DEMYDOVA, 2022 Cilt: 23, Sayl: 1, ss.362-384.

Koronavirus Menyayet Traditsii: Verbnoye Voskresen'ye I Paskha V Moskve Proydut PoNovomu [Coronavirus Changes Traditions: Palm Sunday and Easter in Moscow Will Be Held in a New Way]. (2020, April 12). Vesti.ru. https://www.vesti.ru/article/2398074

Letopis' Yeparkhial'noy Zhizni [Chronicle of Diocesan Life]. (2020, March 21) Predstavitel' Sankt-Peterburgskoy Yeparkhii Prinyal Uchastiye $V$ Diskussii $O$ Tsifrovizatsii Obshchestva [A Representative of the St. Petersburg Diocese Took Part in a Discussion on the Digitalization of Society]. http://eparchia.patriarchia.ru/db/text/5610427.html

Luchenko, K. (2020, March 30). Shiroko Zakrytyye Dveri. Chto Sluchilos' S Russkoy Tserkov'yu Vo Vremya Pandemii. [Doors Wide Shut. What Happened to the Russian Church During the Pandemic]. Carnegie Moscow Center. https://carnegie.ru/commentary/81681

Metropolitan of Pskov and Porkhov Tikhon (Shevkunov). (2021, February 7). Ob"Yavlyayetsya Sbor Materialov Dlya Podgotovki Proslavleniya Startsa Pskovo-Pecherskogo Monastyrya Arkhimandrita Ioanna (Krest'yankina). [Announced the Collection of Materials for Preparation of the Gloralization of the Starets of Pskovo-Pechersk Monastery Archimandrit Ioann (Krestyankin)]. Pravoslavie.ru. https://pravoslavie.ru/137215.html

Mitropolit Ilarion Obespokoyen Sud'boy Fresok Svyatoy Sofii, Prevrashchennoy V Mechet' [Metropolitan Hilarion is Concerned About the Fate of the Frescoes of Hagia Sophia, Turned into a Mosque]. (2020, July 24). Vesti.ru. https://www.vesti.ru/article/2433206

Mozaiku s Putinym Ubrali Iz Khrama Minoborony [Mosaic with Putin Removed from the Temple of the Ministry of Defense]. (2020, May 1). Lenta.ru. https://lenta.ru/news/2020/05/01/mosaic/

Patriarkh Kirill Ob"Yasnil, Dlya Chego Chelovechestvu Dan Koronavirus [Patriarch Kirill Explained Why the Coronavirus Was Given to Humanity]. (2020, April 12). Interfax. https://www.interfax.ru/russia/703812

Patriarkh Kirill Prizval Posmotret' Na Koronavirus Kak Na «Milost' Bozhiyu» [Patriarch Kirill Urged to Look at the Coronavirus as "The Grace of God"]. (2020, March 22). Kommersant. https://www.kommersant.ru/doc/4299209

Patriarkh Kirill Raskritikoval "Nerazumnykh Svyashchennikov" [Patriarch Kirill Criticized "Unreasonable Priests"]. (2020, March 29). Vesti.ru. https://www.vesti.ru/article/2353280

Patriarkh Kirill Utverdil Protivokoronavirusnyye Molitvy I Prizval "Podumat', Chto Vse Eto Oznachayet". [Patriarch Kirill Approved Anti-Coronavirus Prayers and Urged "To Think About What it All Means"]. (2020, March 22). Vesti.ru. https://www.vesti.ru/article/2087875

Patriarkh Poprosil Vlasti Ob Otsrochke Kommunal'nykh Platezhey Dlya Tserkvey [Patriarch Asked Authorities to Defer Utility Bills for Churches]. (2020, April 21). RBC. https://www.rbc.ru/business/21/04/2020/5e9eb8659a79475bee0c769c

Pochemu lyudey Volnuyet Roskosh' Svyashchennosluzhiteley: Vnimaniye Privlekayut Tol'ko Skandaly [Why People Care About the Luxury of Clergy: Only Scandals Attract Attention]. (2019, April 18). MK.ru. https://www.mk.ru/social/2019/04/18/pochemulyudey-volnuet-roskosh-svyashhennosluzhiteley-vnimanie-privlekayut-tolkoskandaly.html 
Polovina Rossiyan Otmetila Vliyaniye RPTS Na Obshchestvennuyu Zhizn' V RF [Half of Russians Noted the Influence of the Russian Orthodox Church on Public Life in the Russian Federation]. (2020, March 22). RIA Novosti. https://ria.ru/20200322/1569675475.html

President of Russia. (2020, March 25). Ukaz Ob Ob"Yavlenii V Rossii Nerabochikh Dney. [Decree Declaring Non-Working Days in Russia]. http://kremlin.ru/events/president/news/63065

Prosveshchennyy Russkiy Natsionalist: Bol'she Dvukh Let Nazad «Dukhovnik Putina» Tikhon Shevkunov Udalilsya Iz Moskvy V Pskov. «Meduza» Vyyasnila, Zachem On Eto Sdelal [Enlightened Russian Nationalist: More Than Two Years Ago, Putin's "Confessor" Tikhon Shevkunov Left Moscow for Pskov. Meduza Found Out Why He Did it]. (2021, February 4). Meduza. https://meduza.io/feature/2021/02/04/prosveschennyy-russkiynatsionalist

Russian Orthodox Church. (2020a, March 17). Sostojalos' Zasedanie Komissii Mezhsobornogo Prisutstvija Po Cerkovnomu Upravleniju, Pastyrstvu I Organizacii Cerkovnoj Zhizni. [Meeting of the Inter-Council Presence Commission on Church Administration, Pastorship and Organization of Church Life]. http://www.patriarchia.ru/db/text/5608740.html

Russian Orthodox Church. (2020b, March 18). Mitropolit Volokolamskij Ilarion: Russkaja Cerkov' Ne Rassmatrivaet Vozmozhnost' Otmeny Bogosluzhenij Iz-Za Jepidemii. [Metropolitan Hilarion of Volokolamsk: The Russian Church Does Not Consider the Possibility of Canceling Services Due to the Epidemic]. http://www.patriarchia.ru/db/text/5609405.html

Russian Orthodox Church. (2020c, March 24). Mitropolit Volokolamskiy Ilarion: Ne Boish'sya Zarazit'sya Sam, Podumay O Drugikh [Metropolitan Hilarion of Volokolamsk: You are Not Afraid to Get Infected Yourself, Think About Others]. http://www.patriarchia.ru/db/text/5612210.html

Russian Orthodox Church. (2020d***, March 26). Pravovoye Upravleniye Moskovskoy Patriarkhii Prokommentirovalo Postanovleniye Pravitel'stva Sankt-Peterburga, Soglasno Kotoromu Zapreshchayetsya Poseshcheniye Khramov. [The Legal Department of the Moscow Patriarchate Has Commented on the Resolution of the Government of St. Petersburg, According to Which it is Prohibited to Visit Churches]. http://www.patriarchia.ru/db/text/5613196.html

Russian Orthodox Church. (2020d**, March 26). Russkaya Pravoslavnaya Tserkov' Zapuskayet V Sotsial'noy Seti «Odnoklassniki» Proyekt Onlayn-Obshcheniya So Svyashchennikami [The Russian Orthodox Church Launches a Project of Online Communication with Priests on the Odnoklassniki Social Network]. http://www.patriarchia.ru/db/text/5613106.html

Russian Orthodox Church. (2020d*, March 26). Rabochaya Gruppa Pri Patriarkhe Moskovskom I Vseya Rusi Prokommentirovala Rekomendatsii Vlastey Vozderzhat'sya Ot Poseshcheniya Religioznykh Ob"Yektov. [The Working Group Under the Patriarch of Moscow and All Russia Commented on the Recommendations of the Authorities to Refrain from Visiting Religious Sites]. http://www.patriarchia.ru/db/text/5613064.html 
Viktoriia DEMYDOVA, 2022 Cilt: 23, Sayl: 1, ss.362-384.

Russian Orthodox Church. (2020e, March 31). V Sinodal'nom Otdele Po Sotsial'nomu Sluzheniyu Sformirovany Gruppy Svyashchennikov I Dobrovol'tsev Dlya Kruglosutochnoy Pomoshchi Bol'nym [The Synodal Department for Social Service Has Formed Groups of Priests and Volunteers to Help the Sick Around the Clock]. http://www.patriarchia.ru/db/text/5615180.html

Russian Orthodox Church. (2020f, May 3). Poslaniye Svyateyshego Patriarkha Kirilla V Nedelyu 3-Yu Po Paskhe, Svyatykh Zhen-Mironosits [Epistle of His Holiness Patriarch Kirill on the 3rd Week After Easter, Holy Myrrh-Bearing Women]. http://www.patriarchia.ru/db/text/5631474.html

Russian Orthodox Church. (2020g, May 21). Mery Gosudarstvennoy Podderzhki V Period Pandemii Rasprostranyat Na Religioznyye Organizatsii [State Support Measures During the Pandemic Will Be Extended to Religious Organizations]. http://www.patriarchia.ru/db/text/5639818.html

Russian Orthodox Church. (2020h, July 23). Startoval Mezh"Yeparkhial'nyy Fotoproyekt "Tserkov' V Period Pandemii» [The Inter-Diocesan Photo Project "Church in the Period of a Pandemic" Has Started]. http://www.patriarchia.ru/db/text/5667821.html

Saratovskiy Mitropolit Vystupil Protiv Zakrytiya Tserkvey Na Paskhu [Saratov Metropolitan Opposed the Closure of Churches for Easter]. (2020, April 18). Kommersant. https://www.kommersant.ru/doc/4326051

Sergey Sobyanin's Website. (2020, March 26). Koronavirus. Zakrytiye Restoranov I Parkov. [Coronavirus. Closing Restaurants and Parks]. https://www.sobyanin.ru/koronaviruszakrytie-restoranov-i-parkov

Shchipkov, A. (2021). Pandemiya Koronavirusa I Budushcheye Russkoy Pravoslavnoy Tserkvi [The Coronavirus Pandemic and the Future of the Russian Orthodox Church]. Rusnarod.ru. http://rusnord.ru/dayly/47373-pandemija-koronavirusa-i-buduschee-russkojpravoslavnoj-cerkvi.html

Soldatov. A. (2020. March 26). «Milost' Bozhiya» Ili Morovaya Yazva? ["The Grace of God" or a Pestilence?]. Novaya Gazeta. https://novayagazeta.ru/articles/2020/03/26/84523-milostbozhiya-morovaya-yazva

St. Petersburg's City Administration. Official Website. (2020, March 26). Gubernator Podpisal Postanovleniye O Novykh Merakh Po Protivodeystviyu Rasprostraneniyu Koronavirusnoy Infektsii. [Governor Signs Decree on New Measures to Counter the Spread of Coronavirus Infection]. https://www.gov.spb.ru/press/governor/185757/

Svyashchennik Rasskazal, Kogda V Khramakh RPTS Zakonchatsya Den'gi Iz-Za Epidemii [The Priest Told When the Churches of the Russian Orthodox Church Will Run Out of Money Due to the Epidemic]. (2020, May 8). RIA Novosti. https://ria.ru/20200508/1571128294.html

Tomilin, O. (2020, May 2). Iz-Za Koronakrizisa Pskovskaya Yeparkhiya Otmenila Tserkovnyye Vznosy I Organizovala Pomoshch' Svyashchennikam I Sotrudnikov Khramov [Due to the Coronavirus Crisis, the Pskov Diocese Canceled Church Fees and Organized Assistance to Priests and Church Staff]. Komsomol'skaya Pravda. https://www.pskov.kp.ru/online/news/3858690/ 
Tserkov' I Nalogi. O Chem Govoryat Prikhozhane, Svyashchenniki I Vlasti [Church and Taxes. What Parishioners, Priests, and Authorities are Talking About]. (2019, June 26). RIA Novosti. https://ria.ru/20190626/1555912016.html

Velikanov, P. (2020a, April 12). Koronavirus I Tserkov': Promezhutochnyye Itogi [Coronavirus and the Church: Interim Results]. Bogoslov.ru. https://bogoslov.ru/article/6026984

Velikanov, P. (2020b, April 19). Paskha 2020, ili Kto v Dome Khozyain? [Easter 2020, or Who's the Boss?]. Bogoslov.ru. https://bogoslov.ru/article/6027214

WCIOM. (2021). Deyatel'nost' Obshchestvennykh Institutov [Activities of Public Institutions]. https://wciom.ru/ratings/dejatelnost-obshchestvennykh-institutov/ 
Viktoriia DEMYDOVA, 2022 Cilt: 23, Sayl: 1, ss.362-384.

\section{EXTENDED ABSTRACT}

COVID-19 pandemic that started to spread around the world in late 2019, posed a threat not only to the stability of the Russian government or Russian economy, but also affected Russian Orthodox Church (ROC). This article problematizes position of ROC that faced the following dilemma. On the one hand, closed churches could not provide spiritual and moral support to the people who sought a reinforcement in the times of pandemic and economic deterioration. In contrast, decision to continue services would mean ignoring statistics of the growing number of the COVID-19 cases in the country. Furthermore, Russian Orthodox Church could not get donations, that are important source of income for the Church; while other sources such as sale of candles and services were cut as well. This put many periphery units of the Church onto the brink of poverty. This article seeks to answer the question about the impact of the COVID-19 pandemic on Russian Orthodox Church in the period between March 2020 and October 2021. It is argued that ROC has been affected by the pandemic in many ways. First, ROC had a disagreement with the Russian government. Till the last minute, churchmen were resisting decision of authorities to close the churches. But as soon as Patriarch Kirill had urged for home prayers, it became clear that the 'symphony of powers' was no longer existing. Rather, the Church appears to be under the control of the state. Second, COVID-19 pandemic posed a threat to the position of ROC in Russian society: flock had distanced from the Church due to the isolation measures adopted. Third, financial contributions of the citizens deteriorate that had led to the financial crisis within the Church. Fourth, COVID-19 pandemic and corresponding measures of the authorities jeopardized existing cleavages between different groups of clergy in ROC. While the radical conservative part desires to continue religious services in Russian churches and opposes their closing, liberal group of clergy urges people for home prayers. Finally, pandemic caused not only new challenges, but also new opportunities for ROC. Among them, there is a chance to launch online services in order to avoid gap between flock and the Church. Second, the Church has the chance to redefine its ideology and worldview in order to address new challenges of the post-COVID world.

This article is a case study of the changes in Russian Orthodox Church's during COVID19 pandemic. Data collection techniques include analysis of the official documents of the Russian government, presidential decrees, local administration and releases of ROC and churchmen accompanied by the study of the media content related to ROC. The time period covered in this article is between March 2020 and October 2021.

Case study of the pandemic's impact on the Church allows us to come up with the following conclusions. COVID-19 and, what is more important, corresponding decisions of the Russian authorities provoked serious crisis in ROC. Pandemic could not pass unnoticed for the Church: existing issues, such as a split among clergy or dissatisfaction with the corrupted nature of the Church aggravated. Long lasting division of the clergy into liberal and conservative has grown during the pandemic due to the opposite views as to the bans on mass gatherings. Conservative group underlined its adherence to the institution of the Church, while liberals demonstrated their humanism and expressed concerns about the health of the people. This split went further and undermined enduring support of the Church to the state since the conservative group of clergy demanded to neglect official measures of the health authorities.

Nevertheless, ROC proved to be a tool of the government when the cathedrals were closed and the services for the people were banned. In this way, ROC failed to perform its most important function - to support the people spiritually and morally, although some priests were 
working online via hot lines or were distributing aid. While Church proved to be another ministry of the state, dissatisfaction with the way government's foreign and domestic policies affect the Church, has grown. Economic crisis also affected ROC but its degree was different for different regions. While churches and cathedrals in the big cities, such as Moscow or St. Petersburg, did not feel the lack of donations significantly, provincial units that do not run businesses, for instance, candle factories or production of the souvenirs, were put to the edge of poverty. The latter had to raise funds to maintain the buildings, pay bill and salaries for the staff.

Furthermore, when it comes to the new, post-COVID Church, one can trace two important tendencies. Both groups, liberal and authoritarian, tried to understand the meaning of the pandemic. While the liberal group of the priests used the opportunity to call for reforms that would make Church more democratic and transparent, much as disrupting its power vertical, authoritarian part of ROC is calling for martyrdom or suffering in the name of the institution of the Church. As it can be seen in the example of the Metropolitan Tikhon (Shevkunov), authoritarian component of the Church is likely to get stronger since incumbent Russian Patriarch Kirill has failed to manage the numerous crises.

Another relevant issue is the use of the Internet, which also appeared to be dividing the representatives of the Russian Orthodoxy into two groups. While conservative group of the clergy rejects any online technologies except of the electronic libraries, liberal group actively uses them to support laity and promote reforms. Blogs, hot lines, social media are the channels of the clergy. Correspondingly, those young Russian Orthodox Internet users have a potential to become a social base for the transformations in the Church.

To conclude, pandemic, among others, demonstrated the need for reforms in the Church. Unification, modernization, humanistic approach, use of technologies are the keys for the stable place of the Church in Russian society, where it already occupies the second most important position. 